\title{
RISK PERCEPTION IN FAMILY HEALTH WORK: STUDY WITH WORKERS IN SOUTHERN BRAZIL
}

Marta Regina Cezar-Vaz Jorgana Fernanda de Souza Soares ${ }^{2}$ Paula Pereira de Figueiredo ${ }^{3}$ Eliana Pinho de Azambuja ${ }^{4}$ Cynthia Fontella Sant'Anna ${ }^{5}$ Valdecir Zavarese da Costa

Cezar-Vaz MR, Soares JFS, Figueiredo PP, Azambuja EP, Sant'Anna CF, Costa VZ. Risk perception in family health work: study with workers in Southern Brazil. Rev Latino-am Enfermagem 2009 novembro-dezembro; 17(6): $961-7$.

This analytical and qualitative study aimed to identify how workers in the Family Health Strategy perceive the risks they are exposed to at work. Thematic analysis and the reference framework of the work process were used to examine the contents of interviews with 48 subjects (community health agents, nurses, nursing auxiliaries and physicians). The workers noticed the following risks: physical and moral violence, typical work accident, emotional exhaustion, lack of problem-solving ability and occupational disease. The results predominantly show the connection with the object / subject of the work and the social environmental characteristics of the related communities. The study adds to the body of knowledge and can systemize collective and individual technological processes for occupational health risk management in primary health care.

DESCRIPTORS: risk; workers; working environment; primary health care

\section{PERCEPCIÓN DEL RIESGO EN EL TRABAJO EN SALUD DE LA FAMILIA: UN ESTUDIO CON TRABAJADORES EN EL SUR DE BRASIL}

Este es un estudio analítico, de naturaleza cualitativa, que tuvo como objetivo identificar la percepción de los trabajadores de la Estrategia en Salud de la Familia, sobre los riesgos a los cuales están expuestos en el trabajo. Se utilizo el análisis temático y el referencial del proceso de trabajo para examinar el contenido de las entrevistas de los 48 sujetos (agentes comunitarios de salud, enfermeros, auxiliares de enfermería y médicos). Los riesgos percibidos por los trabajadores fueron: violencia física y moral, accidente típico de trabajo, desgaste emocional, irresolutividad del trabajo y enfermedad relacionada al trabajo. Los resultados apuntan predominantemente para la relación con el objeto/sujeto del trabajo y las características socio ambientales de las comunidades adscritas. El estudio contribuye para aumentar el conocimiento, pudiendo sistematizar procesos tecnológicos colectivos e individuales para la gestión de los riesgos a la salud del trabajador en la atención básica.

DESCRIPTORES: riesgo; trabajadores; ambiente de trabajo; atención primaria de salud

\section{PERCEPÇÃO DO RISCO NO TRABALHO EM SAÚDE DA FAMÍLIA: ESTUDO COM TRABALHADORES NO SUL DO BRASIL}

Este é um estudo analítico, de natureza qualitativa, que objetivou identificar a percepção dos trabalhadores da Estratégia em Saúde da Família, sobre os riscos aos quais estão expostos no trabalho. Utilizou-se análise temática e o referencial do processo de trabalho para examinar o conteúdo das entrevistas dos 48 sujeitos (agentes comunitários de saúde, enfermeiros, auxiliares de enfermagem e médicos). Os riscos percebidos pelos trabalhadores foram: violência física e moral, acidente típico de trabalho, desgaste emocional, irresolutividade do trabalho e doença relacionada ao trabalho. Os resultados apontam predominantemente para a relação com o objeto/sujeito do trabalho e as características socioambientais das comunidades adstritas. O estudo contribui para o somatório de conhecimentos, podendo sistematizar processos tecnológicos coletivos e individuais para a gestão dos riscos à saúde do trabalhador na atenção básica.

DESCRITORES: risco; trabalhadores; ambiente de trabalho; atenção primária à saúde

${ }^{1}$ RN, Ph.D. in Nursing Philosophy, Associate Professor, Escola de Enfermagem, Universidade Federal do Rio Grande, Brazil, e-mail: cezarvaz@vetorial.net. ${ }^{2}$ RN, Doctoral Student in Public Health, Universidade Federal da Bahia, Brasil, e-mail: jfss_rs@hotmail.com. ${ }^{3}$ Doctoral Student, Universidade Federal do Rio Grande, Brazil. Assistant Professor I, Universidade Federal do Pampa, Brazil, e-mail: paulapfigueiredo@yahoo.com.br. ${ }^{4}$ RN, Ph.D. in Nursing, Adjunct Professor, Colégio Técnico Industrial, Universidade Federal do Rio Grande, Brazil, e-mail: gama@vetorial.net. ${ }^{5}$ RN, Master's Student, Universidade Federal do Rio Grande, Brazil, e-mail: cy kuasenurse@hotmail.com. ${ }^{6}$ RN, Doctoral Student, Universidade Federal do Rio Grande. Assistant Professor I, Universidade Federal do Pampa, Brazil. E-mail: valdecircosta2005@yahoo.com.br. 


\section{INTRODUCTION}

This paper discusses a study on the emerging discourse of workers on the risks they perceive to be exposed to in the work process within the Family Health Strategy (FHS) in Rio Grande, RS, Brazil.

The motivation for the proposed research started from a literature review about the theoretical approach of risk perception. On this occasion, the researchers observed the coherence and the need to analyze the issue of human risk in work environments, in the relation with workers, which includes social, cultural and political aspects in its production and reproduction, by workers and by society in general ${ }^{(1-}$ 3). In this research, this approach was adopted, in which risk can be understood as the perception of danger and its existence is related with individuals or groups (FHS workers), who understand it through rational and social representations, and live with it through specific practices (work process in the FHS).

It was verified in literature that research on risks for workers' health in work environments predominantly contribute to the establishment of causal links between the technological actions that entail visible risks for these workers' bodies and their immediate connection with the knowledge of work physiopathology, with special attention for work accidents ${ }^{(4)}$ in hospital contexts ${ }^{(5-6)}$. Another relevant aspect, distinct from the presented proposal, is the fact that these studies use the occupational risk approach, which was not adopted in the present study, as risks cannot be classified as stricto sensu occupational. In many situations, including the characteristics of communities and work conditions the workers are inserted in, these are not necessarily explained as influencing these workers' health/disease process.

According to the theoretical orientation this research assumed, it is presupposed that, in the specificity of family health work, risks can be perceived in distinct ways and, by knowing and experiencing them in this process, workers reelaborate their knowledge so as to satisfy perceived social needs in the relation with the objects/subjects of health actions and the team, as well as in the intermediation with work instruments. Thus, they incorporate and produce particular risk concepts ${ }^{(1-3)}$ that are developed into collective expressions.

Consequently, that theoretical and empirical content guided the present research, which aims to identify how Family Health Strategy (FHS) workers perceive the risks they are exposed to in their work process, attempting to relate them with the constituent elements of this primary health care process ${ }^{(7)}$. In view of the above, this research can contribute to the development of risk prevention and health production $^{(7)}$ strategies for workers in their work environment.

\section{METHOD}

This is a cross-sectional study with a dialectic approach $^{(8)}$, adding qualitative thematic analysis ${ }^{(9)}$ of workers' risk perception as a constituent dimension of the work process.

The study scenario was the primary family health care network in Rio Grande, a city in the extreme South of Rio Grande do Sul, Brazil. The research sample consisted of 13 of the $20 \mathrm{FHS}$ teams that existed in the semester before data collection. For selection purposes, the following criteria were used to include subjects/teams in the sample: team formation time longer than six months, worker's activity time in the team longer than six months, existence of all workers in the team and representativeness of one professional from each category. A simple draft was used to select community health agents. Fifty-two workers were selected to participate in the research, four of whom were considered lost because they were absent from the Basic Health Unit after three interview attempts. Thus, the final sample consisted of 48 subjects from 13 teams.

Data were collected in June and July 2006, through recorded semistructured interviews. The interview script was tested through a pilot study, involving a family health team that was not included in the sample group, and structured in two parts: a questionnaire to characterize the subjects (gender, age, education), and the interview script itself, guided by the following question: how do FHS workers (community health agent, nursing auxiliary, nurse and physician) perceive the risks they are exposed to in their work process?

Interviews were digitalized and analyzed in NVivo 7.0. With the help of this tool, a (Tree) matrix was constructed for qualitative analysis of the theme ${ }^{(9)}$. For this purposes, a priori defined categories were used, based on the theoretical framework of the work 
process $^{(10)}$, which in this study particularly refers to the worker and the constituent elements of work: the object/subject of the action, the instruments, the product and the general organization of the set of work actions. The work organization expresses how and which factors are intrinsic in its accomplishment; the work object is the population under the teams' responsibility and the socio-environmental contexts ${ }^{(7)}$ that characterize it; the instruments are the means through which the work is accomplished, which are inserted between the work itself and the product, the latter of which is the result itself of the work. Other empirical categories, defined a posteriori, starting from thematic analysis, based on data and supported by the classification of risk related to the work environment ${ }^{(11)}$, were: typical work accident (occurring in the work environment), work-related disease, emotional exhaustion, lack of problem-solving ability and physical and moral violence. It is highlighted that the same workers may have appointed one or more senses of risks they perceive they are exposed to in the development of their work, presented in the relation with the interviewees' testimonies.

Approval for the research proposal was obtained from the Health Research Ethics Committee at Rio Grande Federal University. All interviewees agreed to participate din the research by signing two copies of a post-informed consent term. Ethical guidelines were respected in line with Resolution 196/ 96 by the National Health Council. The interviewed workers were identified with an acronym for their category ( $N=$ nurse, $M d=$ physician, $N A=$ nursing auxiliary, ACS=community health agent) followed by the Arabic numeral corresponding to their individual identification in the database.

\section{RESULTS AND DISCUSSION}

The research subjects were 48 workers: 13 (27.1\%) nurses, 10 (20.8\%) physicians, 12 (25\%) nursing auxiliaries and $13(27.1 \%)$ community health agents. Most workers were women (45-93.75\%). Their mean age was 38.278 .56 (mean \pm standard deviation) years, ranging from 19 to 57 years. Twentythree professionals had a higher education degree (nurses and physicians), 14 (60.87\%) of whom were specialists in Family Health.

The "typical work accident" risk perception was identified in 12 of the 48 testimonies (Two CHA, three $\mathrm{NA}$, one $\mathrm{N}$ and six $\mathrm{Md}$ ). Eight of these (three $N A$, one $N$ and four $M d$ ) mentioned handling piercingcutting material and biological fluids as a conditioning element, in a direct relation with the work object, as the following statement reveals: I work with a syringe, perforation, the patient's blood can jump onto you mucous tissue (Md 7). In three other testimonies (two $\mathrm{CHA}$ and one $M D)$, the socio-environmental characteristics near the Family Health Units were appointed, particularly the presence of electrical fences, dogs, horses and poisonous animals. These are the conditioning factors professionals are confronted with due to the home visits. Also, in one physician's statement, the physical characteristics of the Family Health Unit were appointed as a conditioning factor for risk in the work routine, as evidenced in the transcript of his discourse: installations are small here [...] I hit my head there at the door, I cannot modify that condition (Md 14).

The perception of risks for accidents at work was directly related with the characteristics of the action and the surrounding socio-environmental context. Accidents with piercing-cutting material were considered most recurrent, because they cause exposure to blood and body fluids. These are characterized in the object/subject for the nature of the action, in the individual dimension of work. This kind of risk reveals the act in the body of a person who can cause contamination through infectious agents, like in the case of Hepatitis B and C viruses and Human Immunodeficiency Virus (HIV), in the examples the interviewees mentioned. This risk has been widely studied in literature as a risk for workers' health in hospital services ${ }^{(5-12)}$ and, although less intensely, in the primary health care network ${ }^{(4)}$.

In the same context of clinical knowledge, with regard to the disease itself, ten testimonies evidenced the perception of "work-related disease" (five $\mathrm{CHA}$, three $\mathrm{N}$ and two Md). On the whole, in the direct relation with the object/subject of the action, the conditioning element in six workers' discourse (three $\mathrm{CHA}$, one $\mathrm{N}$ and two $\mathrm{Md}$ ) was associated with exposure to airway secretions, like in the example: contamination by diseases like tuberculosis (Md 45). Or, once again, in the relation with the socio-environmental characteristics of the related communities, as two $\mathrm{CHA}$ reported in the following example: catch [...] jiggers, ticks, like that... (ACS 16), the possibility of catching some parasitic disease. In addition, some conditioning factors were associated with risk perception, directly related with the physical and organizational conditions 
of work: the internal physical environment at the basic unit, which one nurse mentioned: small environment (...) I have sinusitis myself all the time (N 14); and the full-time work journey, in line with another nurse: we are confined in here, so we live the person's problem very closely (...) I feel anxious, I feel stressed, I get high blood pressure sometimes (N 34).

Confinement at the unit, due to the work journey, is considered a risk for professional illness, as staying at the unit full-time makes the workers have contact with the community's problems all day. Countless studies have already demonstrated the association between work conditions and chronic damage, such as cardiorespiratory damage for example, in the same way as the possible transmission of infectious and parasitic diseases ${ }^{(11)}$. It is known, however, that examples of parasitic diseases, as mentioned by the interviewees, are not included in the list of work-related diseases.

The "emotional exhaustion" risk perception was identified in 11 testimonies (two $\mathrm{CHA}$, six $\mathrm{N}$ and three Md). Directly referring to the work object, the worker's bond with people living in precarious conditions in the related communities was the conditioning element found in six workers' reports (two $\mathrm{CHA}$, three $\mathrm{N}$ and one $\mathrm{Md}$ ), as illustrated by the following statement: we are really damaged emotionally, we feel literally sucked out, we get really close (Md 6) or, also, we get sick in their place, because you live everything they live ( $\mathrm{CHA} 31$ ). Another conditioning factor is the work rhythm provoked by the demand, related to the organization of work and the community's need for attention, as one nurse stated: the demand is enormous (N 25). Yet another conditioning factor is expressed by the management's demand for productivity, as two workers expressed (one $\mathrm{N}$ and one $\mathrm{Md}$ ): due to the requirement of data, papers, reports (...) you don't get any feedback on your efforts and charges are high (N 43). The limit itself of work is acknowledged as a conditioning factor of emotional exhaustion, as two workers mentioned (one $\mathrm{N}$ and one $\mathrm{Md}$ ): we cannot solve it (...) that's your frustration (N 30) and we get stressed because we do not manage to do things (Md 17).

The perception of emotional exhaustion as a risk is mainly related to the needs presented by the object/subject of the action, represented by the different groups in the related communities, and to the organization of the work so as to attend to these needs. Hence, work in itself can represent a conditioning factor for the referred emotional exhaustion and, in addition, for the physical/bodily exhaustion provoked by the dialectical nature of the work - qualitative and quantitative at the same time. The fact means that the workers, by developing the bond with the individuals and groups, assume the demanded needs in qualitative and quantitative terms. This translates the precarious living conditions and lack of care of the related populations. Besides, a large number of people need to be attended to, turning FHS work quite intense and extensive. This way, the work produces repetition, which is not mentioned in the testimonies as the reproduction of actions that can cause musculoskeletal alterations ${ }^{(11)}$ but, instead, as the cause of discouragement and frustration in workers. These feelings arise from the workers' efforts to solve the clients' health problems, often without managing to achieve modifications in the subject/object of the action, so as to achieve the satisfaction of the required needs.

The workers acknowledge the productivity and work rhythm demanded by the local FHS management as a conditioning factor for emotional exhaustion. This can occur because the local management is directly responsible for what is produced and, consequently, for the commitment assumed by the local government in view of federal demands, with a view to receiving the financial resources needed for the operational management of the FHS. In the same context, there is a search for activities that represent, in a way, pressure towards increasing productivity, which can provoke increased risks, raising the potential of accidents, work-related diseases and exhaustion typical of the presented work conditions $^{(11)}$. This risk approximates another sense of risk the workers perceive, i.e. the risk of health work "not solving problems", which can be identified as a conditioning factor for and a risk in itself.

Ten workers mentioned perceiving the risk of "not solving problems", related to the organization of the work that imposes limits to achieve the product (one $\mathrm{NA}$, four $\mathrm{N}$ and five $\mathrm{Md}$ ). According to three physicians, one conditioning element for emotional exhaustion is related to insufficient support from the municipal management, like in the following testimony: you manage to organize things locally but, as soon as you leave your territy, you don't get any response anymore (Md 3); to insufficient support from other sectors, clearly appointed in: not having your own resources, for example, water supply problems, contaminated water [...] needs constant monitoring...(Enf 9) or, also, to the limit of the team's work organization, as illustrated by two interviewees' 
statements (one Md and one $\mathrm{N}$ ): not managing to solve their [related population] problems because of the bottlenecks we face (...). We are the part that receives most pressure because the user wants to receive care, we want to give care and, sometimes, we do not manage to solve this impasse (N 21). As a risk in itself, the elements that condition the lack of problem-solving ability are as follows: the sociocultural characteristics of the community that determine nonadherence and bonding with the FHS proposal, according to the extracts of testimonies by five workers (one $\mathrm{NA}$, three $\mathrm{N}$ and one $\mathrm{Md}$ ): presenting and explaining and not accepting the program (NA 2) and, in another more specific example of the medication treatment adherence problem, the patient not adhering to the treatment, he cannot buy the drugs ... (Md 8).

In this sense, the perception of the risk of the work's lack of problem-solving capacity focused on achieving its product or not. This risk expresses the meaning of local team actions' problem-solving capacity, in the relation with forwarding to services these team themselves refer to, in the need for integrated work with other municipal sectors, with a view to solving the communities' socio-environmental problems that go beyond the care actions the workers deliver. Moreover, they are related with the cultural characteristics of people who do not adhere to the teams' care. The set of factors conditioning the risk for lack of problem-solving capacity is connected with the technological instruments used and this object/ subject's need for care in the organization of the work process. And this can be clarified because the FHS represents the first level in the Health System for individual and collective health, through health promotion actions with problem-solving capacity, as well as prevention and control actions for most problems in the territory ${ }^{(13)}$. Due to its central position in the achievement (or not) of the work product, the risk perception reveals a positive, factual element. The risk perception under analysis here tends to suggest that workers acknowledge the object of the action as a subject of their work's success. In this sense, risk perception, like any other knowledge, manifests competing values and is constructed and re-elaborated, as a phenomenon that constitutes social exchanges and constructs individual and collective meanings ${ }^{(14)}$.

Twenty-three (five $\mathrm{CHA}$, five $\mathrm{NA}$, seven $\mathrm{N}$ and six $\mathrm{Md}$ ) of the 48 interviewed workers mentioned the perception of risk for "physical and moral violence". In their testimonies, this perception seems to be directly connected with the object/subject of the action, that is, the conditioning element centered on the sociobehavioral characteristics of the social groups in the related communities, as illustrated by the next two statements: in the poorest population there's more violence, drugs use, assaults, verbal aggression and physical aggression (N 13), or: [...] you expose yourself more and, if the population does not understand your work, some people will fight, discuss and lose their temper. Then you have to know how to handle this because, if you don't, in a while, you'll be the one getting hit! It has already happened, but thanks God things have already calmed down and now we can talk well (N 47).

These characteristics, such as the capacity to be physically and morally aggressive towards the workers, developed through the conceptions and customs of a certain group or person, are related to the more general aspects of current society, which is definitely a "society of risks"(2). Besides, they may be associated with more specific cultural aspects, such as non-adherence and lack of understanding of the health work by people in the communities. One noticeable aspect is that all participants mentioned their perception of the risk of "physical and moral violence" in the relation with the work object as a conditioning element ${ }^{(15-16)}$. Studies demonstrate that the main source of violence refers to the client/patient and relatives, or even to the existence of other sources of possible aggression, like the relations with colleagues or with the immediate head ${ }^{(16-17)}$

This fact can be explained given that, in the particularity of family health care, the team consists of a small number of workers, in which all members, in one way or another, have direct contact with people in the community, due to the FHS proposal itself. In this contact, service users may not feel satisfied, which can give rise to conflicting situations to the extent of favoring some violent act against the worker. And the meanings of this context may implicitly be related with the socio-historical context, in which risks become concrete.

\section{FINAL COMMENTS}

The analysis of the set of data about how the workers perceive the risk for typical work accidents, work-related diseases, emotional exhaustion, "lack of problem-solving capacity" of work and physical and moral violence revealed no evidence to present risk perception differences among teams or job categories, 
which can be considered a study limitation and refers to other intended studies.

On the other hand, in line with the analysis, it can be confirmed that, in summary, the workers' perception in relation to the constituent elements of the work process ${ }^{(10)}$ was constituted as follows: with respect to the object of work, the statements revealed the risks related to typical work accidents, work-related diseases, emotional exhaustion and violence; risks perceived in relation to work organization included work accidents, work-related disease, emotional exhaustion and lack of problem-solving ability of work. In the perception of risks related to work instruments, work accidents and lack of problem-solving capacity of the work stood out. As for risks related to the product of the work, work-related diseases, emotional exhaustion and lack of problem-solving capacity of health work were identified.

As a result of the analysis, it can be highlighted that risk assumes the sense of resulting from the possibility that adverse situations will occur. In its meaning, structural prevision is associated with indetermination ${ }^{(2,14)}$. Prevision is directly connected with the FHS work process as, by knowing its operating structure and theoretical proposal, workers can identify and acknowledge the possible risks immanent in the process. On the other hand, it is affirmed that indetermination is mainly represented through the relation between workers and their work and another element, which they do not control. In the findings, the other element mainly referred to another subject, either the object/subject of the (individual, collective) action and the socio-environmental characteristics of his/her community or other groups of workers/works (health management and other municipal sectors). This (or these) indetermination(s) suggest the extent to which the relation between previewing and knowing the range of conditioning factors of a risk is necessary, so that work management can produce workers' health. It becomes equally important to understand that the same element, depending on the perceived and experienced situation, can be a conditioning factor or a risk in itself.

Based on the statements, the negative sense attributed to risk can also be apprehended, as it "is the translation of a threat, of a danger to the person subject to the risk and who perceives it as such"(14). In addition, it is considered that "there is no risk without a population or an individual who perceives it and who could suffer its effects. Risks are run, which are assumed, refused, stimulated, assessed, calculated"(14).

In this study, risk perception was apprehended as a set of individually and collectively constructed meaning, starting from the workers who produce and reproduce similar and different forms at the same time. And these forms of knowing the social phenomenon in question, i.e. the human risk in the work environment - can influence the workers' health production in their work environment positive or negatively. In the study context, based on the findings, the importance of risk analysis can be inferred in the relation with the constituent elements of the work process, so as to put in practice actions to prevent diseases and promote workers' health.

It should also be highlighted that the authors' interpretation exercise did not intend to offer a classification of the perceived risks, as the analysis is limited by the nature of the object itself, that is, the subjects' perception of the risks they feel they are exposed to. That means saying that there is a slight difference among their different interpretations, which also prevails in relation to the constituent elements of the work process. This demonstrates the need for risk management in work environments, like in primary care, so as to add knowledge with a view to systemizing and undertaking a teaching and learning process, proceeding in such a way that it results in collective and individual technologies for FHS workers' health.

\section{REFERENCES}

1. Slovic P. Perception of Risk. Science 1987; 236:280-5.

2. Hayes $M V$. On the epistemology of risk: language, logic and social science. Soc Sci Med 1992 August; 35(4):401-7. 3. Barnett J, Breakwell GM. Risk perception and experience: hazard personality profiles and individual differences. Risk Anal 2001; 21:171-7.
4. Chiodi MB, Marziale MH, Robazzi ML. Occupational accidents involving biological material among public health workers. Rev Latino-am Enfermagem 2007; 15(4):632-8. 5. Marziale MHP, Rodrigues CM. A produção cientifica sobre acidentes de trabalho com material pérfuro-cortante entre trabalhadores de Enfermagem. Rev Latino-am Enfermagem 2002; 10(4):571-7.

6. Monteiro CM, Benatti MCC, Rodrigues RCM. Occupational 
accidents and health-related quality of life: a study in three hospitals. Rev Latino-am Enfermagem 2009; 17(1):101-7. 7. Cezar-Vaz MR, Muccillo-Baisch AL, Soares JFS, Weis AH, Costa VZ, Soares MCF. Nursing, environment and health conceptions: an ecosystemic approach of the collective health production in the primary care. Rev Latino-am Enfermagem June 2007; 15(3): 418-25.

8. Lefebvre H. Lógica formal, lógica dialética. $6^{a}$ ed. São Paulo (SP): Civilização Brasileira; 1995.

9. Green J, Thorogood N. Qualitative methods for health research. London (UK): Sage; 2005.

10. Marx K. Manuscritos econômicos e filosóficos. Lisboa (PT): Edições 70; 1993.

11. Ministério da Saúde (BR). Doenças relacionadas ao trabalho: manual de procedimentos para os serviços de saúde. Brasília (DF): Ministério da Saúde; 2001.

12. Rapparini C. Occupational HIV infection among health care workers exposed to blood and body fluids in Brazil. Am J Infect Control 2006; 34(4):237-40.

13. Ministério da Saúde (BR). Portaria $n^{\circ} 648$, de 28 de Março de 2006. Aprova a Política Nacional de Atenção Básica, estabelecendo a revisão de diretrizes e normas para a organização da Atenção Básica para o Programa Saúde da Família e o Programa Agentes Comunitários de Saúde. Diário Oficial da União. República Federativa do Brasil. Ministério da Saúde, Gabinete do Ministro. Edição n 61 de 29/03/2006. 14. Veyret $Y$, Richemond NM. O risco, os riscos. In: Veyret $Y$, organizadora. Os riscos: o homem como o agressor e vítima do meio ambiente. São Paulo (SP): Contexto; 2007. p. 23-4. 15. Klijn TP, Suazo VS, Moreno MB. Violencia percibida por trabajadores de Atención Primaria de Salud. Cienc enferm [versión on-line]. 2004 Dic [citado 2008 agos 18]; 10(2): 53-65. Disponible en: http://www.scielo.cl/scielo.php?script= sci_arttext\&pid=S0717

16. Silva $K L$, Sena RR, Leite JCA. A gerência e a violência no âmbito da Unidade Básica de Saúde. REME Rev Min Enferm. $2004 ; 8(1): 177-81$.

17. Camelo SHH, Angerami ELS. Sintomas de estresse nos trabalhadores atuantes em cinco núcleos de saúde da família. Rev Latino-am Enfermagem 2004; 12(1):14-21. 